\title{
Investigation of Current Digital Divide between University Lecturers and Students in the English as a Foreign Language Context in North Bali
}

\author{
Ni Nyoman Artini, Made Hery Santosa, Ni Komang Arie Suwastini \\ English Education Department, Universitas Pendidikan Ganesha, Indonesia \\ nymartini10@gmail.com
}

First draft received: 29 March 2020 Date Accepted: 10 Sept 2020 Final proof received: 1 Dec 2020

\begin{tabular}{|l} 
Abstract \\
Many experts argue that the digital divide has shifted from a gap in access to a gap in the skill to use \\
information and communication technology (ICT). However, some people still have difficulties in getting \\
access to ICT despite the advancement and increasing access and affordability of technology. Reflecting \\
on this problem, this study aimed at finding out whether the digital divide between the lecturers and \\
students of English as a Foreign Language existed and in what aspects the digital divide happened. This \\
research was quantitative, with the data collected through an online survey involving 12 lecturers and 88 \\
students in their third year. The findings revealed that both the gap in access and the gap in use existed \\
between both groups. The result calls for the attention of the stakeholders and policymakers on the \\
improvement of the quality of access to ICT as well as on the advancement in the use of technology, \\
especially for the teachers so that they can keep up with the younger generation. \\
Keywords: Digital divide; English language learning; e-learning; ICT \\
\hline \hline \\
To cite this paper (in APA style): \\
Artini, N. N., Santosa, M. H., \& Suwastini, N. K. A. (2020). Investigation of current digital divide between \\
university lecturers and students in the English as a foreign language context in North Bali. International \\
Journal of Education, 13(2), 113-121. doi: 10.17509/ije.v13i2.23828 \\
\hline
\end{tabular}

\section{INTRODUCTION}

The fourth wave of the industrial revolution has integrated many aspects of life through digitalization and mechanization in many fields (Acilar, 2011; Elwick et al., 2013; Lase, 2019). As part of the Industrial Revolution, information and Communication Technology (ICT) also has advanced development in many sectors such as education, finance, and health (Cieslikowski et al., 2009). In the field of economy, the digital economy proliferates in countries in Southeast Asia, in the Middle East and North Africa (MENA) region, and the Sub-Saharan Africa (SSA) region (Azali, 2017; Bahrini \& Qaffas, 2019). While in the field of education, a shift has happened in terms of penetration of technology into the classroom (Lase, 2019; Sossa et al., 2016). Despite those advancements, the world is still facing the digital divide issue (Alexander, 2017; Elwick et al., 2013; Sossa et al., 2016; Van Dijk, 2012; Wang et al., 2018).

The digital divide is characterized by inequality in accessing the internet and ICTs (Acilar, 2011; Noll et al., 2001; Paprock, 2006; Riggins \& Dewan, 2005). In other words, it is marked by the contrasting difference in the availability of access to ICTs among the people. However, this notion is no longer sufficient as the digital divide contains multilevel issues to be addressed, such as the disparities of age, gender, income, education, geographical location, economic level, and physical ability (Acilar, 2011; Elwick et al., 2013; Vartanova \& Acharya, 2017; World Summit on the Information Society (WSIS), 2007). Vartanova \& Acharya (2017) concluded that the current digital divide is affected by socio-political, socio-cultural, and socio-economic differences, while Elwick et al. (2013), van Deursen \& van Dijk (2014), and Van Dijk (2012) argued that the current digital divide relies on the differences in the usage of ICT moving towards data literacy. Thus, the digital divide's current state distinguished the quality of ICT usage in the groups of different socio-political, socio-cultural, and socioeconomic differences.

A recent survey on Internet penetration in Indonesia showed that $64.8 \%$ of the Indonesian population had access to the internet, with $10 \%$ of users' growth percentage every year (APJII, 2019). It means that Indonesia currently has passed the first level of the digital divide, referring to the availability of access to ICT. However, the survey conducted by APJII (Indonesia Internet Service Provider Association) revealed that there had been a digital divide in terms of age among Indonesian internet users. Those over the age of 60-64 years had only 
around $16 \%$ of internet penetration, while citizens aged 65 years or older had only around $8 \%$ of percent internet penetration.

Meanwhile, internet penetration for the age range of $20-24$ years reached $88.5 \%$. In a more detailed age range, it was revealed that there was an internet penetration of $82.7 \%$ of the $25-29$ year age group, $76.5 \%$ in the $30-34$ year age group, and $35-39$ year age group with a $68.5 \%$ penetration. The gap reflects the high digital divide in Indonesia in terms of age. Given that the millennial generation consists of mainly school-age children at the high school level (15-19 years old) with $91 \%$ internet penetration, the survey implies that digital divides also exist between teachers and their students.

In line with the trend of Education 4.0, Indonesia has been promoting online learning in various levels of education (Baliportalnews, 2019; Balipost, 2018, 2019; Sevima, 2019). As reported by Sevima (2019), Indonesia has developed an online learning system known as SPADA (Indonesian for online learning system), which enables university students to take credit transfer or join courses in other qualified universities across Indonesia. Assuming the equity in equipment and access both among the students and the teachers, the present study was contextualized in the shifting trends of the digital divide and focused on whether the digital divide had shifted to the quality of access and the type of activity performed online between the teachers and the students, or it stayed in terms of inequality of access.

\section{Digital Divide: The Elements and the Shifts}

The shift in the digital divide has been studied by Elwick et al. (2013) in the United Kingdom, specifically for school students. Their study found that in the United Kingdom, digital access was no longer a problem for the students as 95\% of their households had internet access at home. Elwick et al. (2013) further highlighted the 'second-level of the digital divide, how the students used the internet in carrying out their education. The findings revealed that although most of the students had the same access to the internet, its use for schoolwork was low among the students whose parents have the lowest income. Therefore, they suggested that the authorities and the government's focus on providing access should be directed at training and support for the students to improve the use of the internet on schoolwork. Van Deursen \& van Dijk (2014) surveyed low-educated people and people without jobs regarding their internet usage. The online surveys involved 1200 people coming from an online panel. Van Deursen \& van Dijk (2014) sought the respondent's amount of time for online activities during their free time. Also, the research collected the information regarding the respondents' age, gender, educational background, experience on the internet, working status, and income. The finding showed the differences of usage between people with lower education and people with medium or higher education in which the former had a more extended time on internet use. The same finding goes for the unemployed respondents, where more hours were spent compared to employed people. The finding also revealed that internet use for personal development was done by those with higher education while the less educated spent their internet hours for gaming and social interaction. Van Deursen \& van Dijk (2014) concluded that some people were excluded from internet activities such as career and personality development due to different motivations and sociocultural backgrounds despite the abundance of information available online. This research also implied the digital divide change was no longer about internet access but rather on how the users are benefited from the resources they possessed.

Vartanova \& Acharya (2017) reviewed the current state of the digital divide and found that the digital divide can be seen from horizontal and vertical points of view. The former refers to the classical digital divide characterized by limited infrastructure, access, and affordability for ICT devices both in developed and developing countries. The second refers to the differences in the quality of digital access, skills of ICT users, ICT usage, and digital income. Vartanova \& Acharya (2017) concluded that the first concept of the digital divide was easier to handle compared to the second since the second digital divide had various hindrances such as language, competence, and knowledge. However, little is known about the current state of the digital divide between the students and the lecturers in the English as a Foreign Language (EFL) context in north Bali. Thus, this research aimed to describe the digital divide existing on both parties that can be used as future consideration in online instruction, especially in terms of digital readiness.

\section{E-Learning in the Context of Education 4.0}

Various kinds of research on e-learning in the context of education have been done previously, mainly regarding the perceptions and practices in online learning (Yousefi, 2011; Kim \& Bonk, 2006; Roddy et al., 2017; Şad \& Göktaş, 2014). Kim \& Bonk (2006) studied the future of online learning in higher education. They conducted a survey involving college instructors and administrators from two online instruction associations in the United States. There were 562 anonymous respondents who filled the online survey out of 12,000 who received the survey invitation through email. The study covered the demography of online instructors, the current technology development on online teaching, the current learner demands development, and the prediction about enhancing pedagogy in online instruction. The study revealed that there was an improvement in the demography of the instructors. The study found that more women instructors were then involved in online instruction when compared to the result of the previous study, which found that men dominated online instruction. In terms of technological support, the participants predicted the rise in the use of course management systems (CMSs), followed by 
video streaming, online tools for testing and examinations, wireless technologies, and broader internet bandwidth. The study also found the trends in learner demands, such as increasing requests for online certification for the associate degree and the rise of blended learning, which call for improvement on the instructor's financial support and teaching competency. However, CMSs was doubted for its effectiveness in promoting high-quality teaching as it put more emphasis on learning management. The respondents believed that this situation demanded online course instructors to be more skillful in terms of pedagogical techniques, especially in virtual collaboration, critical thinking, and engaging the online course participants.

Yousefi (2011) highlighted the occurring misunderstanding between students and instructors in their online learning. They found that the shift from face-to-face instruction to online instruction, causing confusion about the role of the learning parties. They suggested that although online learning enabled a more independent learning atmosphere, teachers should provide the students with engaging course material as well as sufficient feedback to keep the students on track. While the teachers found the students' request was too demanding, Yousefi (2011) suggested that students' readiness for online learning should be improved. Şad \& Göktaş (2014) reviewed the perception of mobile tools for online learning among pre-service teachers. The result showed that laptops were preferable for mobile learning compared to mobile phones, although laptops were less compact between the two devices. The researchers found that laptops enabled quick access to information, promote independent learning and engagement among students in learning. Besides, mobile tools also enabled learners to learn without limitation as they could access their laptops everywhere. Despite those advantages, the cost of the tools and internet connection became the drawbacks in mobile learning. Students with poor ICT skills might also face anxiety during mobile learning.

Further, there was a growing concern about the impact on health due to electromagnetic radiation. On the other hand, Roddy et al. (2017) reviewed the principles for the best online learning situation. They concluded that successful online learning at least consists of skills in communication, technology, and administration, supported with sufficient feedback, response, and support for the students, as well as well-monitored activity. They further elaborated that online learning holds several challenges like a technical problem, imbalanced learning, confusion among the parties, poor motivation, and low performance of the students. They added that along with the increase of communication, technology, and learning effectivity, students' and teachers' competencies should meet the demands of effective online learning (Roddy et al., 2017).

\section{Digital Divide in EFL Context}

Besides the research on online learning, other experts have studied EFL learning in an online environment, such as the study done by Bracher (2013), Fageeh (2015), Kobayashi \& Little (2011), and Winke et al. (2010). Winke et al. (2010) studied the difference in preparation for computer-assisted language learning (CALL) and online language learning in different language courses. Although the students had equal computer access, the students studying non-Roman alphabet languages showed lower computer literacy. The difference in computer literacy was also found across the gender, where the male students were found to be more literate. Despite the students' literacy level, CALL called for complete technological equipment such as microphones and webcams that were rarely found with the students, which affected their competencies.

On the other hand, Kobayashi \& Little (2011) studied EFL learners' perception of blended learning in terms of students' computer literacy and students' attitude on the usefulness of blended learning. The researchers found that three-quarters of the respondents have adequate computer skills. In terms of its usefulness, the students perceived blended learning as satisfying as they could work on their own, repeat the material extensively, and the feature for pause and replay. Based on the findings, it was suggested for the instructors to ensure that all students should be equipped with computer skills before they are enrolled in blended learning.

Wulandari et al. (2019) studied the $21^{\text {st }}$-century cyber-based learning activities in junior high school in South Bali. Their interview resulted in the findings that $70 \%$ of EFL junior high school teachers in the mentioned setting were digital immigrants. Despite teachers' awareness of the importance of technology utilization in their teaching, they struggled with the adaptation of technology into the classroom. On the other hand, the study revealed that the digital native students were not used to integrating technology in their learning as they mainly used their gadgets solely for entertainment. Wulandari et al. (2019) also mentioned Balinese students' culture as collectivist, reticent, and passive and the limited digital literacy among students and teachers explained the limitation in the success of cyber-based learning activities. These findings build on the importance of addressing the existing digital divide between the students and teachers. However, little is known about the current state of the digital divide between the students and the lecturers in the English as a Foreign Language (EFL) context in north Bali. The previously mentioned study informed that the implementation of cyberlearning in south Bali was not yet successful.

Meanwhile, the BPS report (Badan Pusat Statistik/Central Bureau of Statistics) in Bali shows that the percentage of population aged five years and over accessing Information and Communications Technology in South Bali is different from those in North Bali (Badan Pusat Statistik Provinsi Bali, 2020). The report covers ICT access in terms of the use of 
cellular phones, the use of the personal computer, and the use of the internet, showing that the percentage of ICT access in North Bali is lower than that in South Bali. Reflecting on that limitation, this research aimed to describe the digital divide existing on both students and teachers of EFL in North Bali that can be used as future consideration in designing and implementing digitalized instruction.

\section{METHOD}

This research was a quantitative study following Creswell (2012), using an online survey as the instrument of data collection. There were 88 students and 15 lecturers who participated in this study, selected through non-probability sampling. The survey was conducted in January 2019. The participants were selected because they had participated in online learning during their teaching and learning. The students studied English Language Education in a university in north Bali, while the lecturers were teaching at English Language Department in the same university. The students were in their year and had participated in at least one e-learning management system, such as Schoology, Moodle, or the others. An online survey consisting of 19 questions was addressed for the students and the lecturers regarding their ownership of ICT tools and 18 questions regarding their activities online. The questions for the questionnaire followed the survey constructed by Masoumeh et al. (2013). The participants' consent was gained by sending a consent letter requesting their consent to participate in this study. The questions for the questionnaire followed the survey constructed by Masoumeh et al. (2013) in the study entitled A Survey on Existing Digital Divide between Teachers and Students of Girl Schools in Astara County. The questionnaire contained items asking the use of oldfashioned technology since the research subject might still use them, such as using the MP3 player in listening courses. The questionnaire was validated through content validity. An inner sample pretest was conducted to calculate the questionnaire's reliability where Cronbach's alpha coefficient was set 0.796 for the teacher and 0.773 for the students for the section "amount of having equipment." In the "amount of using ICT" section, the Cronbach's alpha coefficient was set to 0.897 and 0.902 for the teachers and students. Further validation was not conducted in this study as the instrument has been validated previously.

The results of the questionnaire were grouped as data gained from EFL teachers and data gained from EFL students. After that, the responses were classified depending on the given answer shown in table 1 and table 2. The classified answers were then counted for the percentage. From this percentage, the responses from both groups were compared to determine the differences in terms of ICT equipment, ICT access, and online activities. Finally, the conclusion was drawn, followed with the suggestion for future EFL learning.

\section{RESULTS AND DISCUSSION Differences in Equipment and Access to ICT between Teachers and Students}

The survey involved 88 students and 15 lecturers regarding the hardware and software equipment accessed by both groups. The result of the survey can be seen in Table 1.

Table 1 shows that the EFL lecturers were equipped with more ICT tools such as computers, printers, and scanners, compared to that of the students. As high as $91.7 \%$ of the lecturers were equipped with computers at home, while the students' possession reached $87.5 \%$. In terms of access to the computer, both groups have a similar degree implying that both groups could involve such technology in the EFL learning process. Moving to the second question regarding possession of printer, more lecturers had a printer at home than those who did not. On the other hand, the students having a printer at home were fewer than those who did not. A similar finding was also seen in the third question regarding the possession of a scanner.

Regarding the possession of printers and scanners, the EFL students were not as equipped as their EFL lecturers. Related to EFL learning, the lecturers may need to consider giving assignments requiring hard copies as the students are required to use printing services for printing and scanning necessary documents. Concerning the fourth question related to the ability to burn an optical disc, neither the students nor the lecturers had the facility that might be due to the rare occasion of using that facility. However, the students were sometimes asked to collect their optical disc assignments, but the printing company usually provided such a service. Therefore, the service was not accessed independently by the students.

Regarding internet connectivity, all lecturers (100\%) were equipped with computers that could connect to the internet, while $12.5 \%$ of the students had computers that could not connect to the internet. Therefore, in terms of internet access, the lecturers had better access than the student did. The lecturers and the students had similarities in terms of webcam features on their computers. Thus, lecturers' computers had more complete features such as burning optical disks, connecting to the internet, and webcam. This finding is in line with findings found by Khalid (2011) and Masoumeh et al. (2013), in which teachers had greater access to ICT hardware. Masoumeh et al. (2013) and Gunduz (2010) further explained that the digital divide in terms of access could come from differences in socio-economic status between the lecturers and the students. While teachers' incomes were at the same level from one to another, the students might come from families with different levels of socio-economic status regarding minimal access to ICT.

Table 1 also shows that the lecturers and the students have different digital access on the campus. In terms of access to a computer, internet connectivity, 
and webcam on the campus, both groups have equal access. However, the differences are seen in the access toward other hardware such as a printer, scanner, and optical disc burner. All of the lecturers $(100 \%)$ had access to that three hardware on the campus, while $41 \%$ of the students had no access to campus printers, $38.5 \%$ of the students had no access to campus scanners, and $41 \%$ of the students did not have access to the optical disc burner. This finding is in line with Masoumeh et al.'s (2013) findings that revealed that a high percentage of students had low access to computers at home, and a small percentage of students had access to school. However, in terms of access to the computer, the present study revealed that the percentage of students having a computer at home is relatively high (87.5\%), showing an increase in ICT access. This situation might have been due to the demonetizing of ICTs, making devices more affordable. These differences in accessing ICT equipment for EFL students and EFL lecturers implied that EFL learning involving ICT might be disrupted since they did not have immediate access to support their learning. However, several adjustments can be made, such as employing group works to minimize the need for individual access or to switch printed-out assignments to soft copies.

In terms of digital television possession, both groups had a similar degree. This finding is in line with the findings of studies conducted by Fajar (2019) and The Nielsen Company (2017), which revealed that digital television penetration was at the rate of $96 \%$ with an average of 5 hours spent on watching television. This percentage is higher than that in Khalid's (2011) study that detected a two-hour daily occupation with television. The Nielsen Company report may explain this high percentage of access to digital television in both groups, as digital television has become more affordable. Concerning the possession of the mobile phone and internet access from it, both groups had full access to it. It can be seen from the question no 13,14 , and 15, where all participants of both groups reported that they had access to a mobile phone, internet connection, and email. Thus, ICT integration in EFL learning can be directed towards activities that can be done through mobile phones, such as learning websites or mobile learning applications. Mobile phones with advanced features utilized for EFL learning may be the solution for the students facing difficulties accessing computers.

In conclusion, limitation towards access to several hardware shows that the digital divide existed among the EFL learners. Therefore, the teachers need to take careful consideration in involving various technology in EFL learning. Avoiding activities involving technology hardly accessed by the students or ensuring that the students are provided with access to necessary technological tools may help deal with the digital divide. Online material and online submission for assignment may be the alternative to deal with students' limitation on access towards the printer, scanner, and optical disc burner.

\section{Differences in Types of Activities Performed Online Between Teachers and Students}

Another interesting issue on the digital divide between the teachers and the students includes the types of activities performed using ICT, as can be observed in Table 2 below. From Table 2, it can be observed that both groups had a similar amount of use in using computers in general, such as typing class material and research. This use included using Microsoft Word software or Microsoft Office Suite, educational software, research or educational materials, chatting online with friends, sending files by email, using popular search engines, shopping online, uploading pictures and videos, and using Social Networking Services. Concerning EFL learning, the lecturers usually use Microsoft Office Suite to present the material using Microsoft Word and Microsoft PowerPoint or using a learning management system for their blended learning. Meanwhile, the students usually use the services mentioned previously to completing their tasks and submitting the assignment to their lecturer. They also attended online classes through a learning management system provided by their lecturers. Reflecting on the similar activities conducted online, these findings reveal the possibility of combining those activities into the learning. For example, as both groups use the internet to upload pictures and videos and use Social Networking Service, the arrangement of learning sequence involving those activities can be an exciting option for EFL learning.

However, while none of the teachers stated that they used ICTs for graphics software, blogging, web designing, and sending files through Bluetooth, around $69 \%$ of the students reported varying degrees of graphic software for these purposes. Thus, in general, the students had more varied internet activities than their lecturers. These gaps existing between the students and their teachers are in line with those found by Khalid (2011) and Masoumeh et al. (2013), where students were revealed to have a higher average on the use of the internet across activities, with Masoumeh et al. (2013) emphasized that the trend was most prevalent among the younger generation. In Indonesia, the findings were also in line with the revelation from Indonesia Internet Service Provider Association (2019), whose survey revealed that the internet penetration rate was the highest among the 15-19 years old age group and 20-24 years old age group. This gap can be used as consideration for EFL lecturers in designing EFL learning activities in North Bali, especially those involving the kinds of activities widely accessed by the students. In other words, having adequate access to digital equipment should be followed with the utilization of those means in EFL learning. In other words, the lecturers also need to improve their digital literacy to facilitate the occurring trend of online activities among their students. 
In conclusion, the present study revealed that the digital divide between the students and the lecturers on the other access provided for both parties remained. However, the digital divide also had shifted in terms of usage, where the students slightly used ICTs more often in various activities such as blogging, graphic editing, web designing, and file sharing compared to their teachers. The shifts are in line with the findings from the World Summit on the Information Society (WSIS) (2007) and Vartanova \& Acharya (2017), who state that the digital divide is no longer about those having and not having access to ICT but also about the skilled and unskilled user of ICT. Therefore, the task to overcome the digital divide is to focus on providing ICT access and providing resources on using technology for more productive use, especially when it concerns educational stakeholders. The recent findings also implied that the current state of the digital divide in EFL learning in North Bali existed in the form of limitation towards digital access and limitation towards utilizing ICT for learning activities. The International Literacy Association (2017) proposed four fundamental steps for facing the current digital divide: funding the facilitation of ICT support, designing pedagogy reflecting the P-21 framework, facilitating teacher training on digital learning, and urging the policymakers to address the digital divide issue. These steps are also applicable for the EFL context in North Bali as the current studies showed the existing gap of digital access among the students and different online activities conducted by the EFL students and EFL lecturers.

\section{Table 1}

\section{Possession of Hardware and Software Equipment by Students and Lecturers}

\begin{tabular}{|c|c|c|c|c|c|c|c|c|}
\hline \multirow{3}{*}{ Questions } & \multicolumn{4}{|c|}{ Yes } & \multicolumn{4}{|c|}{ No } \\
\hline & \multicolumn{2}{|c|}{$\mathrm{L}$} & \multicolumn{2}{|c|}{$\mathrm{S}$} & \multicolumn{2}{|c|}{$\mathrm{L}$} & \multicolumn{2}{|c|}{$\mathrm{S}$} \\
\hline & QTY & $\%$ & QTY & $\%$ & QTY & $\%$ & QTY & $\%$ \\
\hline 1. Do you have a computer at home? & 11 & 91.7 & 77 & 87.5 & 1 & 8.3 & 11 & 12.5 \\
\hline 2. Do you have a printer at home? & 8 & 66.7 & 27 & 30.7 & 4 & 33.3 & 61 & 69.3 \\
\hline 3. Do you have a scanner at home? & 7 & 58.3 & 11 & 12.5 & 5 & 41.7 & 77 & 87.5 \\
\hline 4. Can your computer burn optical discs? & 5 & 41.7 & 11 & 12.5 & 7 & 58.3 & 77 & 87.5 \\
\hline 5. Can your computer connect to the internet? & 12 & 100 & 77 & 87.5 & 0 & 0 & 11 & 12.5 \\
\hline 6. Does your computer have a webcam? & 11 & 91.7 & 61 & 69.3 & 1 & 8.3 & 27 & 30.7 \\
\hline 7. Does your campus have any computers? & 12 & 100 & 83 & 94.3 & 0 & 0 & 5 & 5.7 \\
\hline 8. Does your campus have any printers? & 12 & 100 & 52 & 59 & 0 & 0 & 36 & 41 \\
\hline 9. Does your campus have any scanners? & 12 & 100 & 54 & 61.4 & 0 & 0 & 34 & 38.6 \\
\hline $\begin{array}{l}\text { 10. Can your campus computers burn the } \\
\text { optical disk? }\end{array}$ & 12 & 100 & 52 & 59 & 0 & 0 & 36 & 41 \\
\hline $\begin{array}{l}\text { 11. Can your campus computers connect to the } \\
\text { internet? }\end{array}$ & 12 & 100 & 81 & 92 & 0 & 0 & 7 & 8 \\
\hline $\begin{array}{l}\text { 12. Do your campus computers have } \\
\text { webcams? }\end{array}$ & 9 & 75 & 59 & 68.6 & 3 & 25 & 29 & 31.4 \\
\hline 13. Do you have a mobile phone? & 12 & 100 & 88 & 100 & 0 & 0 & 0 & 0 \\
\hline $\begin{array}{l}\text { 14. Can your mobile phone connect to the } \\
\text { internet? }\end{array}$ & 12 & 100 & 88 & 100 & 0 & 0 & 0 & 0 \\
\hline 15. Do you have an email? & 12 & 100 & 88 & 100 & 0 & 0 & 0 & 0 \\
\hline 16. Do you have a digital television at home? & 9 & 75 & 72 & 81.8 & 3 & 25 & 16 & 18.2 \\
\hline 17. Do you have a fax machine at home? & 0 & 0 & 3 & 3.4 & 12 & 100 & 85 & 96.6 \\
\hline 18. Do you have your own blog or website? & 5 & 41.7 & 13 & 14.9 & 7 & 58.3 & 75 & 85.1 \\
\hline 19. Do you have an MP3 player? & 9 & 75 & 49 & 55.7 & 3 & 25 & 39 & 44.3 \\
\hline
\end{tabular}

\begin{tabular}{lll}
\hline Note: & L & : Lecturers \\
& S & : Students \\
& QTY & : Quantity
\end{tabular}


Table 2

Amount of Use of Information and Communication Technologies

\begin{tabular}{|c|c|c|c|c|c|c|c|}
\hline \multirow[t]{2}{*}{ Item } & \multirow[t]{2}{*}{ Groups } & \multirow{2}{*}{$\begin{array}{l}\text { Statistical } \\
\text { Indicator }\end{array}$} & \multicolumn{5}{|c|}{ Answer } \\
\hline & & & $\begin{array}{l}\text { Very } \\
\text { Low }\end{array}$ & Low & Medium & High & Very High \\
\hline \multirow{2}{*}{$\begin{array}{l}\text { Using computers (in } \\
\text { general) }\end{array}$} & $\mathrm{L}$ & QTY (\%) & $0(0)$ & $0(0)$ & $0(0)$ & $2(16.7)$ & $10(83.3)$ \\
\hline & $\mathrm{S}$ & QTY (\%) & $1(1.1)$ & $2(2.3)$ & $32(36.3)$ & $43(48.9)$ & $10(11.3)$ \\
\hline \multirow{2}{*}{$\begin{array}{l}\text { Typing class materials } \\
\text { and researches }\end{array}$} & $\mathrm{L}$ & QTY (\%) & $0(0)$ & $0(0)$ & $0(0)$ & $3(25)$ & $9(75)$ \\
\hline & $\mathrm{S}$ & QTY (\%) & $0(0)$ & $2(2.3)$ & $33(37.5)$ & $39(44.3)$ & $14(15.9)$ \\
\hline \multirow[t]{2}{*}{ Microsoft Word Software } & $\mathrm{L}$ & QTY (\%) & $0(0)$ & $0(0)$ & $0(0)$ & $1(8.3)$ & $8(91.7)$ \\
\hline & $\mathrm{S}$ & QTY (\%) & $0(0)$ & $2(2.3)$ & $16(18.2)$ & $35(39.8)$ & $34(38.6)$ \\
\hline \multirow{2}{*}{$\begin{array}{l}\text { 4. Other software in } \\
\text { Microsoft Office Suite }\end{array}$} & $\mathrm{L}$ & QTY (\%) & $0(0)$ & $0(0)$ & $3(25)$ & $7(58.3)$ & $2(16.7)$ \\
\hline & $\mathrm{S}$ & QTY (\%) & $1(1.1)$ & $9(10.3)$ & $36(41.0)$ & $34(38.6)$ & $8(9.0)$ \\
\hline \multirow{2}{*}{$\begin{array}{l}\text { 5. Graphics software like } \\
\text { Adobe Photoshop }\end{array}$} & $\mathrm{L}$ & QTY (\%) & $6(50)$ & $4(33.3)$ & $1(8.3)$ & $1(8.3)$ & $0(0)$ \\
\hline & $\mathrm{S}$ & QTY (\%) & $11(12.5)$ & $19(21.6)$ & $41(46.6)$ & $12(13.6)$ & $5(5.7)$ \\
\hline \multirow[t]{2}{*}{ 6. $\quad$ Educational Software } & $\mathrm{L}$ & QTY (\%) & $1(8.3)$ & 0 & $4(33.3)$ & $5(41.7)$ & $2(16.7)$ \\
\hline & $\mathrm{S}$ & QTY (\%) & $2(2.3)$ & $14(16.0)$ & $32(36.4)$ & $33(37.5)$ & $6(6.8)$ \\
\hline \multirow{2}{*}{$\begin{array}{l}\text { 7. Using the Internet for } \\
\text { Research or Educational } \\
\text { Materials }\end{array}$} & $\mathrm{L}$ & QTY (\%) & $0(0)$ & $0(0)$ & $0(0)$ & $0(0)$ & $12(100)$ \\
\hline & $\mathrm{S}$ & QTY (\%) & $1(1.1)$ & $2(2.3)$ & $23(26.1)$ & $31(35.2)$ & $31(35.2)$ \\
\hline \multirow{2}{*}{$\begin{array}{ll}\text { 8. } & \text { Chatting Online with } \\
& \text { Friends }\end{array}$} & $\mathrm{L}$ & QTY (\%) & $0(0)$ & $1(1.1)$ & $1(1.1)$ & $2(2.3)$ & $8(66.7)$ \\
\hline & $\mathrm{S}$ & QTY (\%) & $1(1.1)$ & 0 & $6(6.8)$ & $23(26.1)$ & $58(66)$ \\
\hline \multirow[t]{2}{*}{ 9. $\quad$ Blogging } & $\mathrm{L}$ & QTY (\%) & $6(50)$ & $2(16.7)$ & $1(8.3)$ & $2(16.7)$ & $1(8.3)$ \\
\hline & $\mathrm{s}$ & QTY (\%) & $18(20.4)$ & $18(20.4)$ & $35(39.8)$ & $14(15.9)$ & $3(3.4)$ \\
\hline \multirow{2}{*}{$\begin{array}{l}\text { 10. National network of } \\
\text { schools }\end{array}$} & $\mathrm{L}$ & QTY (\%) & $1(8.3)$ & $3(25)$ & $4(33.3)$ & $4(33.3)$ & $0(0)$ \\
\hline & $\mathrm{S}$ & QTY (\%) & \multicolumn{5}{|c|}{$\begin{array}{l}\text { This question was only asked in the teachers' } \\
\text { questionnaire. }\end{array}$} \\
\hline \multirow{2}{*}{ 11. Web designing } & $\mathrm{L}$ & QTY (\%) & $12(100)$ & $0(0)$ & $0(0)$ & $0(0)$ & $0(0)$ \\
\hline & $\mathrm{s}$ & QTY (\%) & $28(31.8)$ & $22(25.0)$ & $29(32.9)$ & $6(6.8)$ & $3(3.4)$ \\
\hline \multirow[t]{2}{*}{ 12. Sending files by email } & $\mathrm{L}$ & QTY (\%) & $0(0)$ & $0(0)$ & $1(8.3)$ & 4 (33.3) & $7(58.3)$ \\
\hline & $\mathrm{s}$ & QTY (\%) & $1(1.1)$ & $3(3.4)$ & $27(30.6)$ & $33(375)$ & $23(26.1)$ \\
\hline \multirow{2}{*}{ 13. Sending SMSs } & $\mathrm{L}$ & QTY (\%) & $3(25)$ & $3(25)$ & $3(25)$ & $0(0)$ & $3(25)$ \\
\hline & $\mathrm{s}$ & QTY (\%) & $9(10.2)$ & $24(27.2)$ & $35(39.8)$ & $11(12.5)$ & $9(10.2)$ \\
\hline \multirow{2}{*}{ 14. Popular search engines } & $\mathrm{L}$ & QTY (\%) & $0(0)$ & $0(0)$ & $1(8.3)$ & $0(0)$ & $11(91.7)$ \\
\hline & $\mathrm{s}$ & QTY (\%) & $1(1.1)$ & $8(9.1)$ & $22(25.0)$ & $33(37.5)$ & $24(27.3)$ \\
\hline \multirow{2}{*}{$\begin{array}{l}\text { 15. Online or electronic } \\
\text { shopping }\end{array}$} & $\mathrm{L}$ & QTY (\%) & $3(25)$ & $2(16.7)$ & $1(8.3)$ & $3(25)$ & $3(25)$ \\
\hline & $\mathrm{s}$ & QTY (\%) & $7(7.8)$ & $12(13.6)$ & $20(22.7)$ & $26(29.5)$ & $23(26.1)$ \\
\hline \multirow{2}{*}{ 16. Business software } & $\mathrm{L}$ & QTY (\%) & $8(66.7)$ & $2(16.7)$ & $1(8.3)$ & $1(8.3)$ & $0(0)$ \\
\hline & $\mathrm{S}$ & QTY (\%) & $\begin{array}{l}\text { This ques } \\
\text { questionn }\end{array}$ & $\begin{array}{l}\text { on was onl } \\
\text { ire. }\end{array}$ & asked in th & teachers' & \\
\hline 17. Bluetoothing files & $\mathrm{L}$ & QTY (\%) & $5(41.7)$ & $4(33.3)$ & $1(8.3)$ & $2(16.7)$ & $0(0)$ \\
\hline & $\mathrm{S}$ & QTY (\%) & $9(10.3)$ & $22(25.0)$ & $29(32.9)$ & $16(18.2)$ & $12(13.6)$ \\
\hline 18. Uploading pictures and & $\mathrm{L}$ & QTY (\%) & $1(8.3)$ & $0(0)$ & $1(8.3)$ & $4(33.3)$ & $6(50)$ \\
\hline videos & $\mathrm{s}$ & QTY (\%) & $2(2.3)$ & $2(2.3)$ & $21(23.9)$ & $28(31.8)$ & $35(39.8)$ \\
\hline 19. Using Social Networking & $\mathrm{L}$ & QTY (\%) & $1(8.3)$ & $1(8.3)$ & $0(0)$ & $3(25)$ & $7(58.3)$ \\
\hline Services & $\mathrm{S}$ & QTY (\%) & $0(0)$ & $4(4.5)$ & $20(22.7)$ & $31(35.3)$ & $32(36.4)$ \\
\hline 20. Computer games & $\mathrm{L}$ & QTY (\%) & $\begin{array}{l}\text { This ques } \\
\text { questionn }\end{array}$ & $\begin{array}{l}\text { on was only } \\
\text { ire. }\end{array}$ & asked in th & student's & \\
\hline & $\mathrm{S}$ & QTY (\%) & $15(17.0)$ & $14(15.9)$ & $34(38.6)$ & $11(12.5)$ & $14(16.0)$ \\
\hline $\begin{array}{l}\text { 21. Continuous lists of } \\
\text { libraries }\end{array}$ & $\mathrm{L}$ & QTY (\%) & $\begin{array}{l}\text { This ques } \\
\text { questionn }\end{array}$ & $\begin{array}{l}\text { on was on } \\
\text { ire. }\end{array}$ & sked in th & student's & \\
\hline & $\mathrm{s}$ & QTY (\%) & $7(7.9)$ & $20(22.7)$ & $38(43.1)$ & $14(16.0)$ & 9 (10.2) \\
\hline
\end{tabular}




\section{CONCLUSION}

Following the shift in the current digital divide and the shift in education along with the fourth industrial revolution, this research addressed the digital divide between the EFL students and their lecturers. The obtained data showed that there were two kinds of digital divide existing among both groups through the online survey. There was a digital divide in terms of access to ICT and in terms of the use of ICT. The teachers have easier access to ICT than the students, which can be due to their occupational status and income. Although the students were less prepared with the ICT tools, they were more skillful in using technology. Therefore, students may not face many difficulties in operating ICT tools during their learning, although they still need support in terms of tool availability. E-learning may be conducted with careful consideration of students' access to the ICT tools to ensure that unavailable tools do not hinder their learning. Teachers may be required to adjust their tasks and check the required ICT facility before assigning them to them. Furthermore, this situation calls for more training on operating ICT skills for the teacher and more supporting facilities on e-learning for the students to narrow the gap between the teachers and the students.

\section{ACKNOWLEDGEMENT}

The authors would like to express their gratitude towards this research's participants, the students and lecturers, who had spared their time to enroll in the survey.

\section{REFERENCES}

Acilar, A. (2011). Issues in informing science and information technology exploring the aspects of digital divide in a developing country. Informing Science and Information Technology, 8, 231244.

Alexander, B. (2017). Higher education, digital divides, and a balkanized internet. Educause Review, 52(6), 22-34.

APJII. (2019). Penetrasi \& profil perilaku pengguna internet indonesia [Penetration and Internet user behavior profiles Indonesi]. In Asosiasi Penyelenggara Jasa Internet Indonesia. Retrieved from www.apjii.or.id

Azali, K. (2017). Singapore | 14 September 2017 Indonesia's Divided Digital Economy. ISEAS Yusof Ishak Institute, 1-12.

Badan Pusat Statistik Provinsi Bali (Bali Province Centre of Statistics). (2020). Percentage of population aged 5 years and over who accessed of information and communications technology over the last 3 months by regency/municipality, 2019. Retrieved from https://bali.bps.go.id/

Bahrini, R., \& Qaffas, A. A. (2019). Impact of information and communication technology on economic growth: evidence from developing countries. Economies, 7(1), 21-33 https://doi.org/10.3390/economies7010021
Baliportalnews. (2018, May 2). Kemenristekdikti luncurkan sistem pembelajaran perguruan tinggi berbasis daring [The Ministry of Research and Higher Education launched an online based higher education learning system]. Baliportalnews. https://baliportalnews.com

Balipost. (2018, Aug 9). Genjot APK di perguruan tinggi, UT gencarkan pembelajaran daring [Increasing gross enrolment rate, UT promotes online learning). Balipost.com. http://www.balipost.com

Balipost. (2019, Aug 9). Era Revolusi Industri 4.0, PT maksimalkan pembelajaran daring [Higher Education maximizes online learning in industrial revolution 4.0]|. Balipost.com. http://www.balipost.com

Bracher, J. (2013). A survey of online teaching by native-speaker english instructors at japanese universities. JALT CALL Journal, 9(3), 221-239.

Cieslikowski, D., Halewood, N., Kimura, K., \& Qiang, C. Z.-W. (2009). Key trends in ICT development. In Information and Communications for Development (125-132). The International Bank for Reconstruction and Development/The World Bank.

Creswell, J. W. (2012). Educational research planning, conducting, and evaluating quantitative and qualitative research (4th ed.). Pearson.

Elwick, A., Liabo, K., Nutt, J., \& Simon, A. (2013). Beyond the digital divide: Young people and ICT. CfBT Education Trust.

Fageeh, A. I. (2015). EFL student and faculty perceptions of and attitudes towards online testing in the medium of blackboard: promises and challenges. JALT CALL Journal, 11(1), 4162.

Fajar, T. (2019, March 5). Studi Nielsen: Pemirsa Indonesia habiskan 5 jam nonton tv, 3 jam berselancar di internet [Nielsen's study: Indonesian viewers spend 5 hours watching TV, 3 Hours Surfing on the Internet] Okezone Economy. https://economy.okezone.com

Gunduz, H. B. (2010). Digital divide in Turkish primary schools: Sakarya sample. Turkish Online Journal of Educational Technology, 9(1), 43-53.

International Literacy Association. (2017). Literacy leadership brief: overcoming the digital divide four critical steps. 2-6, 1578-1584. https://doi.org/10.4018/978-1-60566-198-8.

Khalid, M. S. (2011). Digital divide between teachers and students in urban bangladesh. Proceedings of the 5th International Technology, Education and Development Conference, 2010-2020.

Kim, K.-J., \& Bonk, C. J. (2006). The future of online teaching and learning in higher education: the survey says... Educause Quarterly (4), 22-30. https://doi.org/10.1016/S0889-8537(05)70296-0

Kobayashi, K., \& Little, A. (2011). Learner perceptions on the usefulness of a blended learning EFL program. JALT CALL Journal, 7(1), 103-117.

Lase, D. (2019). Pendidikan di era revolusi industri 
4.0. Jurnal Sundermann, 1(1), 28-43. https://doi.org/10.36588/sundermann.v1i1.18

Masoumeh, H., Jahangiri, S., Ali, D. B. H., \& Alireza, K. (2013). A survey on existing digital divide between teachers and students of girl schools in astara county. International Journal of Academic Research in Business and Social Sciences, 3(11), 356-375. https://doi.org/10.6007/ijarbss/v3-i11/345

Noll, R. G., Older-Aguilar, D., Rosston, G., \& Ross, R. R. (2001). The digital divide: Definitions, measurement, and policy issues. American Economics Association Meetings, 15.

Paprock, K. E. (2006). The digital divide in developing countries: A case for distance education. Systemics, Cybernetics and Informatics, 4(6), 89-93.

Riggins, F., \& Dewan, S. (2005). The digital divide: Current and future research directions. Journal of the Association for Information Systems, $6(12)$ https://doi.org/10.17705/1jais.00074

Roddy, C., Amiet, D. L., Chung, J., Holt, C., Shaw, L., McKenzie, S., ... Mundy, M. E. (2017). Applying best practice online learning, teaching, and support to intensive online environments: An integrative review. Frontiers in Education, 2, 110. https://doi.org/10.3389/feduc.2017.00059

Şad, S. N., \& Göktaş, Ö. (2014). Pre-service teachers' perceptions about using mobile phones and laptops in education as mobile learning tools. British Journal of Educational Technology, 45(4), 606-618. https://doi.org/10.1111/bjet.12064

Sevima. (2020, Febr 11). Sistem Pembelajaran Daring (SPADA) Indonesia, kuliah millennials [Indonesia Online Learning System, Millenials Course]. https://sevima.com/sistempembelajaran-daring-spada-indonesia-kuliahmillennials/

Sossa, S. F., Rivilla, A. M., \& González, M. L. C. (2016). Digital inclusion in education in tarija, plurinational state of Bolivia. CEPAL Review, (115), 63-80. https://doi.org/10.18356/fa19c5daen

The Nielsen Company. (2017). Penetrasi Media Televisi Masih yang Tertinggi [TV penetration remains high]. https://databoks.katadata.co.id/datapublish/2017 /07/27/penetrasi-televisi-masih-yang-tertinggi

van Deursen, A. J. A. M., \& van Dijk, J. A. G. M. (2014). The digital divide shifts to differences in usage. New Media and Society, 16(3), 507-526. https://doi.org/10.1177/1461444813487959

Van Dijk, J. A. G. M. (2012). The evolution of the digital divide: The digital divide turns to inequality of skills and usage. In J. Bus, M. Crompton, M. Hildebrandt, G. Metakides (eds) Digital Enlightenment Yearbook 2012, (pp. 5775). IOS Press. https://doi.org/10.3233/978-161499-057-4-57

Vartanova, E., \& Acharya, B. B. (2017). Conceptual evolution of the digital divide: A systematic review of the literature over a period of five years (2010-2015). Journal of Russian Media and Journalism Studies, 41-74.

Wang, H., Buzzetto- Hollywood, N., Elobeid, M., \& Elobaid, M. (2018). Addressing information literacy and the digital divide in higher education. Interdisciplinary Journal of E-Skills and Lifelong Learning, 14, 077-093. https://doi.org/10.28945/4029

Winke, P., Goertler, S., \& Amuzie, G. L. (2010). Commonly taught and less commonly taught language learners: Are they equally prepared for CALL and online language learning? Computer Assisted Language Learning, 23(3), 199-219. https://doi.org/10.1080/09588221.2010.486576

World Summit on the Information Society (WSIS). (2007). Bridging the digital divide. In World Information Society $2^{\text {nd }}$ ed. (pp. 20-33). https://doi.org/http://handle.itu.int/11.1002/pub/8 020d0d0-en

Wulandari, C. I. A. S., Aryati, N. P. P. S., \& Permatasari, N. P. I. (2019). Specified 21st cyber-based learning activities perspectives from JHS EFL teachers in Indonesian EFL context. 3rd English Language and Literature International Conference (ELLiC) Proceedings, 3, 263-270

Yousefi, A. (2011). The impact of information and communication technology on economic growth: evidence from developed and developing countries. Economics of Innovation and New Technology, 20(6), 581-596, https://doi.org/ $10.1080 / 10438599.2010 .544470$ 